\title{
Trace elements detection in tissues of fish (Pseudoplatystoma coruscans) caught in the São Francisco river (MG)
}

\section{Elementos traço em tecidos de peixes (Pseudoplatystoma coruscans) capturados no rio São Francisco (MG)}

\author{
Jennifer Matedi Gobbi, ${ }^{*}$ Marília Martins Melo, ${ }^{* *}$ Daniel Vieira Crepaldi, ${ }^{* * *}$ Edgar Alencar Teixeira ${ }^{\star * * *}$
}

\begin{abstract}
Resumo
O Surubim (Pseudoplatystoma coruscans) é um peixe predador encontrado no rio São Francisco (MG), e frequentemente consumido tanto pela população local, como por todo o Brasil. Apesar das grandes vantagens do consumo de peixes na dieta, atualmente, uma das preocupações dos órgãos estaduais e federais é a contaminação por elementos traço nesses peixes. Neste contexto, foi realizado um estudo sobre o teor de mercúrio, chumbo, cádmio, arsênio e zinco em 59 amostras de fígado, baço, rins e em 29 amostras de tecido muscular de surubins capturados em diferentes períodos do ano no rio São Francisco. Nas amostras de fígado e rins foram detectados mercúrio, cádmio, zinco e chumbo em níveis acima dos limites estabelecidos pela legislação brasileira. As amostras de baço também apresentaram cádmio, zinco e chumbo em níveis acima do limite legal. No entanto, no tecido muscular, não foi detectada a presença dos metais aqui analisados acima dos limites permitidos. Observouse uma correlação positiva e diretamente proporcional de $72 \%$ entre os metais estudados e, especialmente entre chumbo e cádmio no baço, de $82 \%$. É importante salientar que, apesar de estes peixes estarem apropriados para o consumo humano, a presença de elementos traço nas amostras estudadas deve servir de alerta para a inspeção periódica da área estudada, em relação não apenas ao consumo humano, mas também pela contaminação ambiental, incluindo toda a fauna e flora.
\end{abstract}

Palavras-chave: espectrofotometria de absorção atômica, chumbo, arsênio, mercúrio, cádmio, zinco, elementos, traço, peixe.

\begin{abstract}
Surubim (Pseudoplatystoma coruscans) is a predator fish found in the São Francisco River in Minas Gerais state, and it is frequently consumed by both the local population as well as people throughout the entire state. Despite the significant advantages of having fish as part of a normal diet, one of the more recent concerns of state and federal governmental agencies is the metal contamination in these catches. In this context, a study was conducted on the content of mercury, lead, cadmium, arsenic and zinc in 59 sample units of liver, spleen, kidney, and muscular tissue from surubim fish captured during different periods of the year in the São Francisco River. The liver and kidney samples presented mercury, cadmium, zinc, and lead contamination at levels above the limits set forth under Brazilian law. The spleen samples also presented cadmium, zinc, and lead contamination at levels above the legal limit as well. However, in muscular tissue, no presence of the metals analyzed herein was detected at above the legal limits. A positive and directly proportional correlation of $72 \%$ was found among metals studied. The positive correlation between of lead and cadmium concentrations in the spleen was $82 \%$. It is important to note that, although these fish are appropriate for human consumption, the presence of metals in these fish samples should serve as a warning for the periodic inspection of the studied area, regarding not only human consumption but also the different biological systems in which all fauna and flora are present.
\end{abstract}

Keywords: spectrophotometer of atomic absorption, lead, arsenic, mercury, cadmium, zinc, trace elements, fish.

\section{Introduction}

Surubim (Pseudoplatystoma coruscans) is a predator fish found in the São Francisco River located in Minas Gerais state (Brazil). This fish has a great commercial value due to the high quality of its meat and the notable presence in commercial fishing. Despite the great nutritional relevance of fish consumption in the human diet, nowadays, one of the main concerns of federal governmental agencies is the metal contamination in those catches. Surubim consumption from the São Francisco River is of most importance to both the riverside population and consumers from many urban centers.

\footnotetext{
* Mestre em Ciência Animal, Escola de Veterinária, UFMG.

** Doutora, professora associada, Depto de Clínica e Cirurgia Veterinárias, Escola de Veterinária, UFMG, Avenida Antônio Carlos, 6627, CEP: 31270 010, Belo Horizonte, Minas Gerais. Corresponding author: e-mail address - mariliamm@ufmg.br

*** Doutor, analista ambiental - Programa Nacional de Desenvolvimento da Pesca Amadora - PNDPA - IBAMA

${ }^{* * * *}$ Professor adjunto, Depto de Zootecnia, Escola de Veterinária, UFMG.
} 
One possible cause of the contamination of these catches is industrial activity, which significantly diminishes the permanence of those metals in the ores, reduces the production of new compounds, and changes the distribution of these elements on the planet (Mager et al., 2008). Metal contamination, among other kinds of contamination present in these catches, should be emphasized as it can be cumulative in an organism. The consequences of human intoxication by metals can be severe, ranging from involuntary shaking to coma and even death, depending on the metal in question (Noureddine et al., 2005).

The large consumption of surubim from the São Francisco River in the state of Minas Gerais, Brazil, and the great concern regarding the contamination of this fish by heavy metals are quite evident. The aim of this study is to analyze the trace elements contamination in surubim fish of São Francisco River, Brazil.

\section{Materials and methods}

The capture of the surubim fish analyzed in this work was carried out in the central area of the São Francisco region, in the city of São Francisco in the state of Minas Gerais, Brazil, where it is still possible to find pure and abundant surubim populations (Pseudoplatystoma coruscans).

Sixteen surubim samples were caught in November 2005, six in January 2006, 16 in June 2006, and 21 in October 2006. Of the total 59 samples, only 20 (of the 21 surubim captured in October 2006) had muscle tissue fragments removed for analysis. From each sample captured, fragments with a minimum mass of 25 grams of muscle tissue and bowels (liver, spleen, and kidneys) were removed for laboratory analyses.

An atomic absorption spectrophotometer (AA-1475 Varian) was used to analyze metal concentrations. The digestion of the samples was the same as the one described by the American Public Health Association (1992) for mercury, lead, cadmium, arsenic, and zinc.

For statistical analysis, 59 fragments of viscera and 20 fragments of muscular tissue were used. For each of the variables, the usual descriptive statistics (medium, standard variation, and coefficient of variation) were defined.

To test the normality and homogeneity of variances of the morphometric data and estimates, the Lilliefors and Bartlett tests were used, respectively. For the concentrations of mercury and cadmium in the liver, spleen, kidney, and muscular tissue, the function $\sqrt{X+1}$ was applied. For lead, arsenic, and zinc in the liver, spleen, kidneys, and muscular tissue, the function $\sqrt{X}$ was applied, where $\mathrm{X}$ represents the real values of the metal concentrations. The samples were divided into groups based on the month in which they were caught so as to analyze the metal contamination in samples at different times throughout the year. Group I was composed of all samples captured in November 2005. Groups II, III, and IV were composed of all samples captured in January, June, and October 2006, respectively.

The comparison of the average obtained in these groups was carried out by the Tukey test $(P<0.05)$. The completely randomized design was employed and the analyses were performed using the SAS 9.0 program.

\section{Results and discussion}

Figure 1 presents values between the concentration of each metal in each liver sample and the maximum tolerable limit of mercury, lead, cadmium, arsenic, and zinc in fish, in regards to the total mass $[\mathrm{kg}]$ of each fish from which the sample was taken.

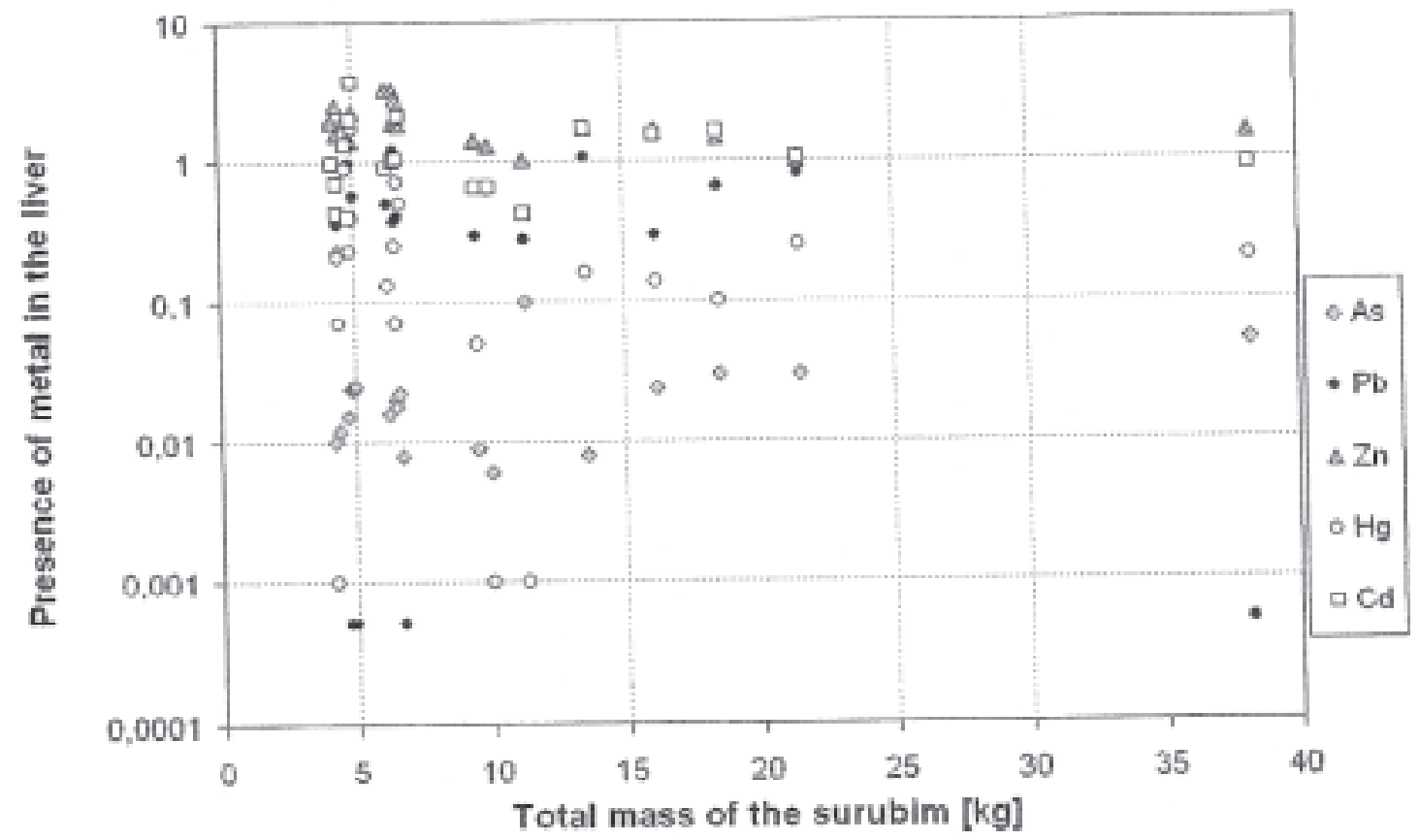

Figure 1: Presence of metals in the liver in regard to the total mass of the surubim [kg] 
Regardless of the metal being analyzed, the samples with a determineted concentration (metal concentration/maximum tolerable limit) higher than the legal limit of $1.0 \mathrm{mg} \mathrm{kg}^{-1}$ are considered contaminated. A logarithmic scale was used to better visualize the points and to better identify contaminated samples.

As shown in Figure 1, the mercury levels among the samples were similar (and within the legal limit), except for two sample units where a hightened concentration of mercury was observed. Using Canada's legal limit opposed to Brazil's, eight samples, instead of two, were above the legal limit. Considering that mercury is a cumulative metal, these results serve as a warning for populations that frequently consume surubim.

A high concentration of lead was observed in the two samples that surpassed the legal limit of $2.0 \mathrm{mg} \mathrm{kg}^{-1}$. Jordão et al. (1999) also reported that the lambari fish species (Astyanax sp.) caught in the river of Conselheiro Lafaiete town (Brazil) presented higher concentrations of lead in its muscles and viscera than that set by Brazilian environmental standards. Despite significant reductions in its usage, most notably in paint production and as a fuel additive, lead continues to enter the environment primarily by anthropogenic background, retaining its status as a major pollutant (Mager et al., 2008). As in mammals, the principal effects of chronic lead exposure to fish are presumably hematological (Schmitt et al., 2002), neurological (NourEdine et al., 2005) and renal (Patel et al., 2006) impairment.

Some samples $(23 \%)$ presented cadmium concentrations above the legal limit of $1.0 \mathrm{mg} \mathrm{kg}^{-1}$. The quantity of cadmium found in smaller fish may well be related to the age of the animal, which influences its metabolic speed, which, in turn, is correlated to the fish's rate of retention and elimination of cadmium through the body. Hence, fish with smaller masses present a faster absorption rate of cadmium. Cadmium is a nonessential heavy metal of high environmental concern due to its toxicity, general usage, industrial production and emissions from fossil fuel combustion (Felten et al., 2008), being for such reasons the priority of some goverments, as it can be seen by the Canadian Environmental Protection Act, 1994. In natural freshwaters, cadmium sometimes occurs at concentrations of less than 0.1igL"1 (USEPA, 2001), but in environments impacted by humans, concentrations may reach micrograms per liter, or even higher values (Bervoets et al., 2005).

In the correlation analysis (Pearson Correlation) between the concentrations of mercury and cadmium in the liver, a positive correlation was found $(72 \%)$; that is, the increase of mercury results in the increase of cadmium. Felten et al. (2008), studying the physiological and behavioral responses of freshwater crustaceans (Gammarus pulex) exposed to cadmium, demonstrated a decrease in feeding rate and locomotor and ventilatory activities. In some studies, inhibition of reproduction was observed in fish of contaminated water by trace elements. Levesque et al. (2003) observed a delayed reproduction of yellow perch (Perca flavescena) in a cadmium-contaminated lake in Canada.

What can be observed is that an impressive number (95\%) of zinc samples in the liver are above the Brazilian legal limit of $50 \mathrm{mg} \mathrm{kg}^{-1}$. In addition, a large number of these samples that possess an excessive quantity of zinc are those fish that possess less corporal mass, which might be related to the capacity of zinc to promote growth.

Figure 2 presents the values between the concentration of each metal in each kidney sample and the maximum tolerable limit of each metal in fish, in regards to the total mass [kg] of each fish from which the sample was taken.

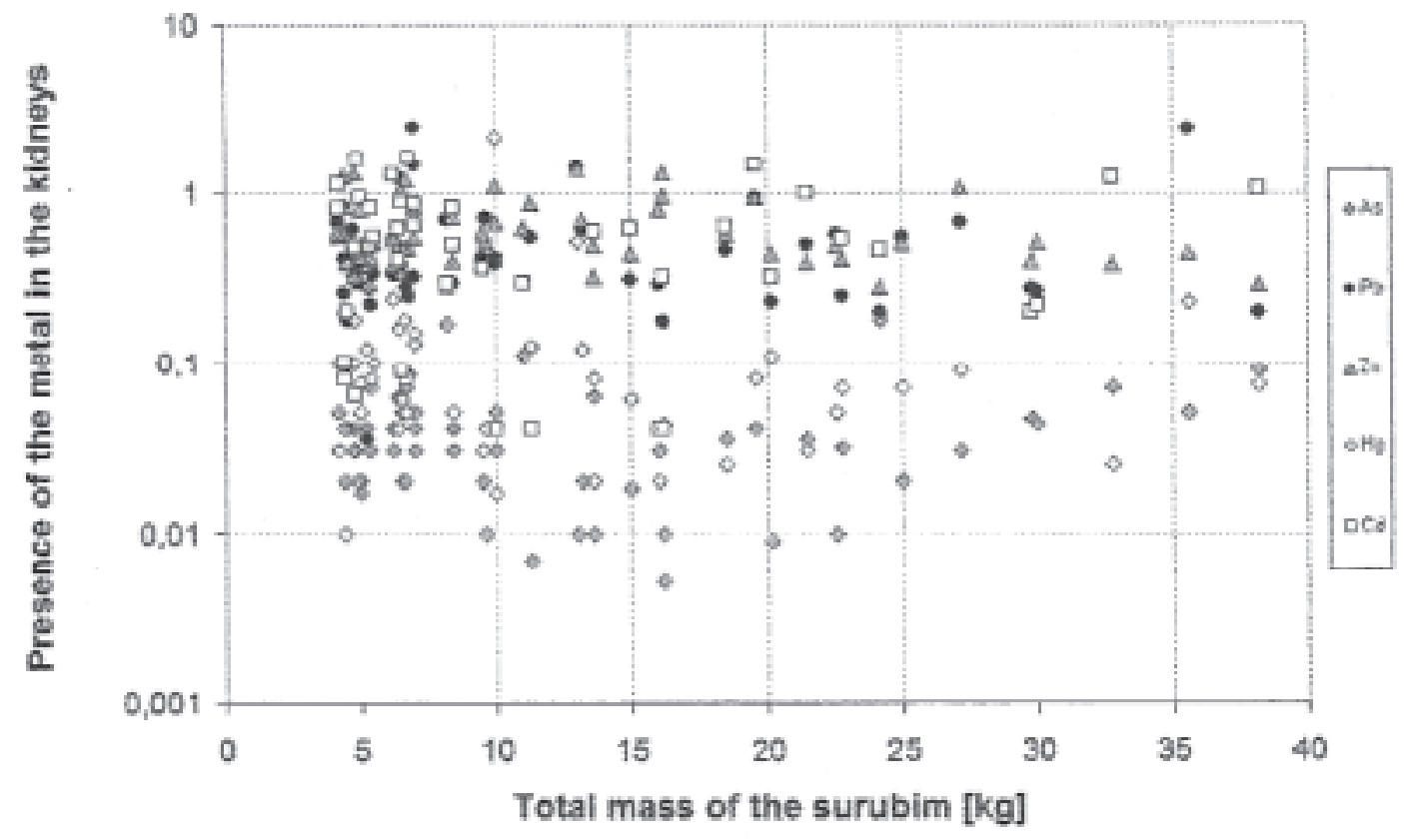

Figure 2: Presence of metals in the kidneys in regard to the total mass of the surubim [kg]. 
The concentrations of mercury found in the kidneys were much lower than the tolerable limit of $1.0 \mathrm{mg} \mathrm{kg}^{-1}$ for fish predators, except in one sample, which presented $2.18 \mathrm{mg} \mathrm{kg}^{-1}$. EaglesSmith et al. (2009) evaluated mercury ( $\mathrm{Hg})$ in five waterbird species representing three foraging guilds in San Francisco Bay (USA). Fish-eating birds (Forster's and Caspian terns) had the highest $\mathrm{Hg}$ concentrations in their tissues, but concentrations in an invertebrate-foraging shorebird (blacknecked stilt) were also elevated. Importantly, Hg concentrations increased with time spent in the estuary. Breeding waterbirds were at elevated risk of $\mathrm{Hg}$-induced reproductive impairment, particularly Forster's terns, in which $48 \%$ of breeding birds were at high risk due to their $\mathrm{Hg}$ levels.

It was found that seven (17\%) kidney samples were above the legal limit of $1.0 \mathrm{mg} / \mathrm{kg}$ for concentrations of cadmium. In general, cadmium concentrations in different foods vary greatly according to their origin in the environment and their concentration in the soil.

In contrast to the samples analyzed in the liver, in which $98 \%$ of the samples were contaminated, in the kidneys, only eight contained a quantity of zinc above the legal limit of $50 \mathrm{mg} / \mathrm{kg}$. Though the legal limit sounds like a small number, such a quantity of zinc can still be very hamful to animal and human health.

Figure 3 presents the values between the concentration of each metal in each spleen sample and the maximum tolerable limit of each metal in fish, in regard to the total mass [kg] of each animal from which the sample was taken.

No spleen sample presented a mercury content above the legal limit of $1.0 \mathrm{mg} / \mathrm{kg}$ for fish predators; however, this does not exclude the existence of mercury in the samples.

Ten spleen samples (17\%) were found to be above the legal limit of $2.0 \mathrm{mg} / \mathrm{kg}$ for lead. Correlation analysis showed a statistically significant correlation of $82 \%$ between the lead and cadmium concentrations in the spleen. The surubim feeds at the bottom of the river, a behavior that may have contributed to the large lead accumulation in fish, since the contamination may arise from both the water as well as sediments. The lead accumulates mainly in the gills, liver, kidneys, and bones. Pace et al. (2005) showed that exposure to $0.1 \mathrm{ppm}$ of lead during the neonatal and adolescent period is sufficient to reduce fertility in adult male mice.

Lead can enter aquatic ecosystems through the discharge of urban, agricultural, and industrial waste (Soto et al., 2004). The low average concentration observed in the fish samples during this experiment may be due to the fact that this element presents a low concentration in the aquatic biota, even when its concentrations in the abiotic surroundings are high.

In the spleen, when comparing lead and cadmium concentrations, it could be observed that the average level of lead was five times greater than that of cadmium. However, when comparing mercury and cadmium, mercury presented a level 10 times greater than that of cadmium.

Figure 4 presents the reason values between the concentration of each metal in each sample of muscular tissue and the maximum tolerable limit of each metal in fish, in regard to the total mass $[\mathrm{kg}]$ of each fish from which the sample was taken.

No sample showed the presence of mercury above the legal limit of $1.0 \mathrm{mg} / \mathrm{kg}$ for fish predators. Nonetheless, in accordance to De Temmerman et al. (2009), mercury is a cumulative metal, and even in low concentrations, it can be harmful to health, especially when ingested frequently together with another food element. The results of the present study are similar to the results from Viana et al. (2005) who, in their research on fish from the Uruguayan coastline, found no mercury concentrations in the muscular structures above the legal limit.

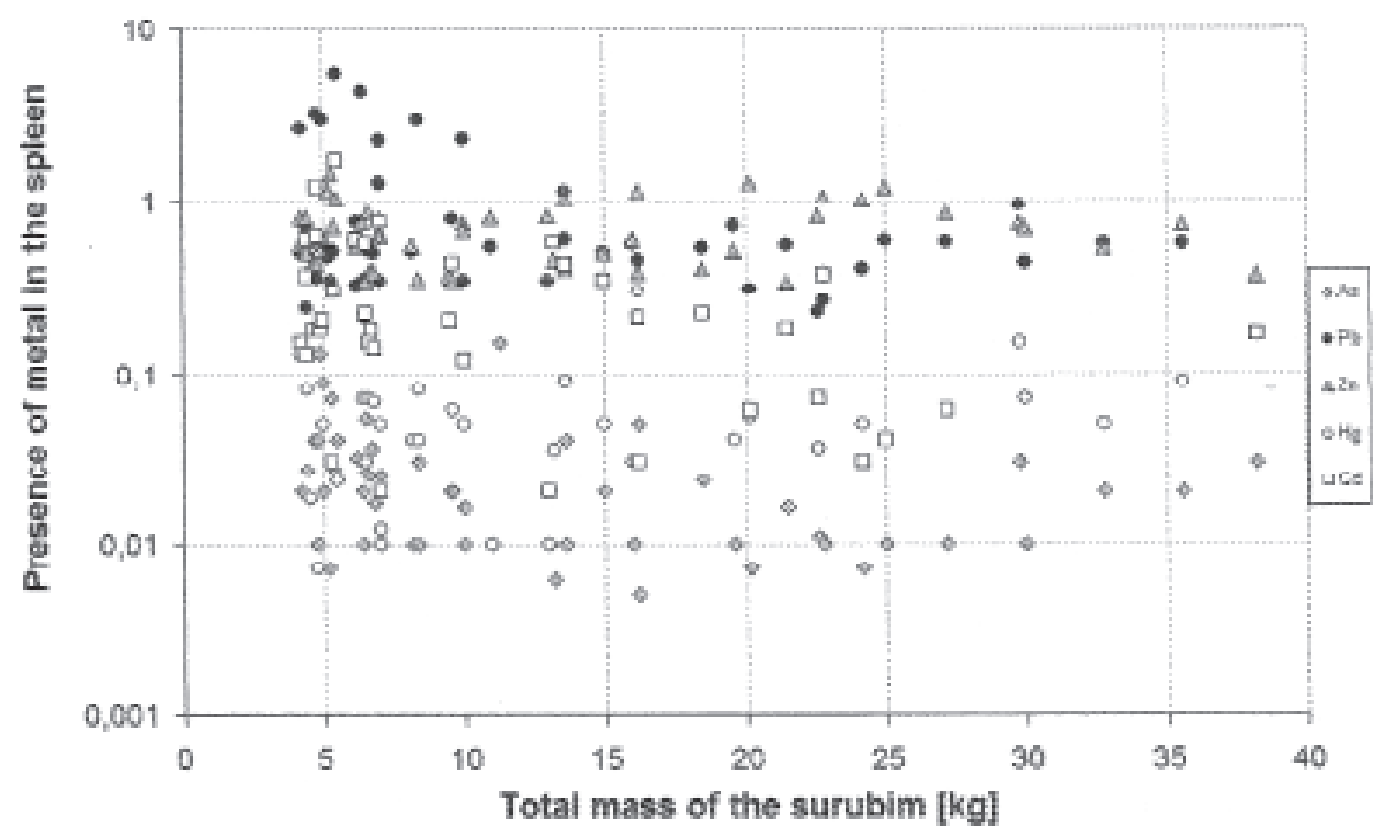

Figure 3: Presence of metals in the spleen in regard to the total mass of the surubim [kg]. 


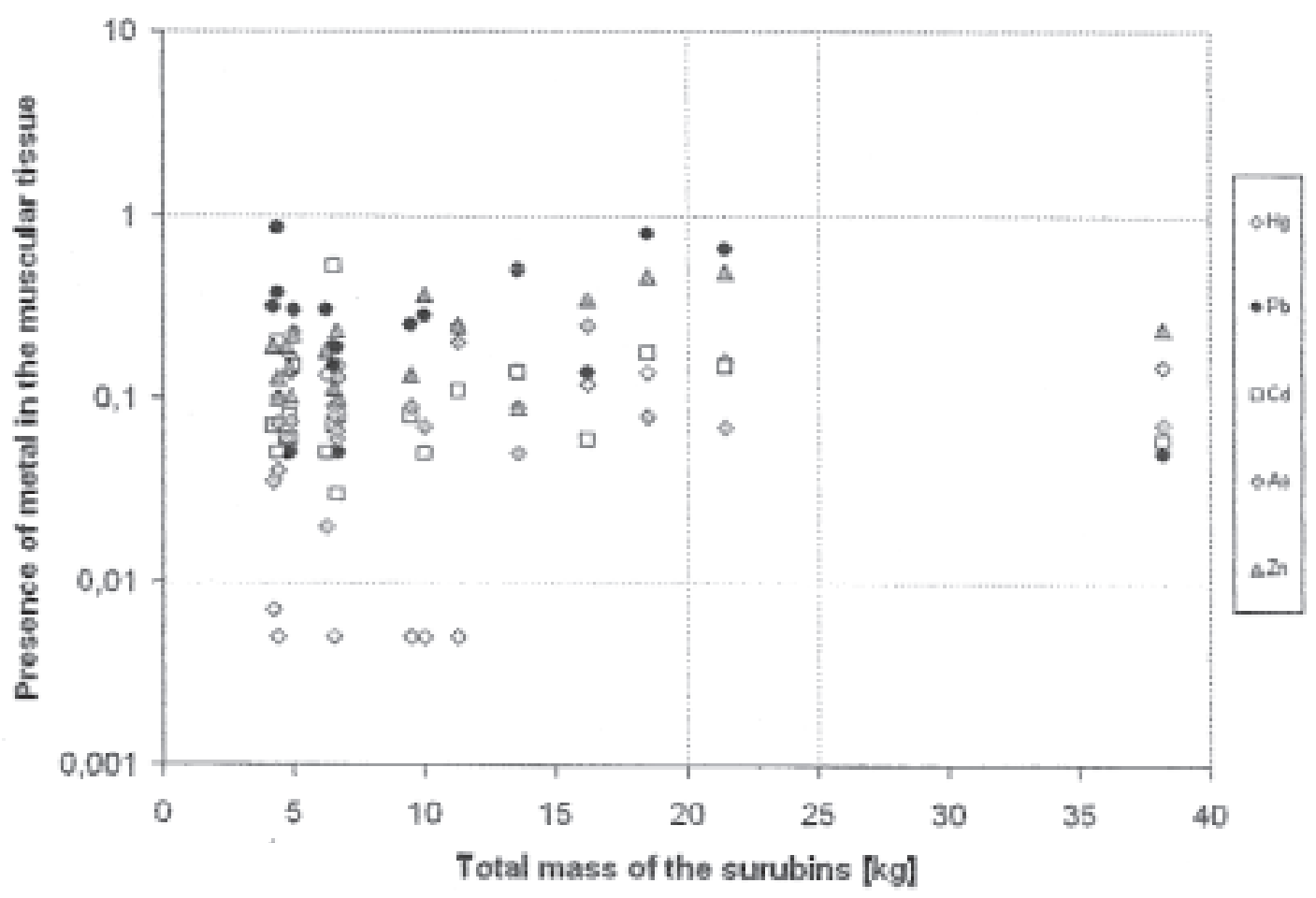

Figure 4: Presence of metals in the muscular tissue in regard to the total mass of the surubim $[\mathrm{kg}]$.

It should be emphasized that no muscular tissue samples showed the presence of cadmium above the legal limit of 1.0 $\mathrm{mg} / \mathrm{kg}$. In the São Francisco River, the activity most commonly reported by the local fishermen as harmful to the river was deforestation of riverbank trees, which provokes mudslides into the river, and which may, in turn, transfer into the river a significant quantity of that metal thus, influencing fish intake.

Table 1 presents the comparisons between the total average of mercury in each organ (liver, spleen, kidney, and muscular tissue) and the coefficient of variation, for a possible analysis of differences found in each fish. Therefore, it was observed that, in the tissues studied, the liver was the organ that presented the highest mercury content. That fact should be emphasized since the local population commonly uses fish liver in its eating habits, especially since the muscular tissue is comercialized.

Table 1: Mercury levels $\left(\mathrm{mg} \mathrm{kg}^{-1}\right)$ of Surubim fish (liver, kidneys, and spleen) in different groups (times).

\begin{tabular}{llll}
\hline \multirow{2}{*}{ Groups } & \multicolumn{3}{l}{ Mercury $\left(\mathrm{mg} \mathrm{kg}^{-1}\right)$} \\
\cline { 2 - 4 } & Liver & Kidneys & Spleen \\
\hline I (Nov/ 2005) & $0,40 \mathrm{a}$ & $0,29 \mathrm{a}$ & $0,06 \mathrm{a}$ \\
II (Jan/ 2006) & $0,23 \mathrm{c}$ & $0,08 \mathrm{~b}$ & $0,05 \mathrm{a}$ \\
III (Jun/ 2006) & $0,08 \mathrm{~d}$ & $0,05 \mathrm{c}$ & $0,02 \mathrm{~b}$ \\
IV(Oct/ 2006) & $0,29 \mathrm{~b}$ & $0,04 \mathrm{c}$ & $0,02 \mathrm{~b}$ \\
\hline CV (\%) & 19,02 & 20,14 & 25,67 \\
\hline
\end{tabular}

Averages followed by distinct letters differ amongst themselves as determined by the Tukey test $(\mathrm{P}<0.05)$

Table 2 presents the comparison of the medium values of mercury $(\mathrm{mg} / \mathrm{kg})$ in the liver, kidneys, spleen and muscular tissue.
Table 2: Comparison of mercury values $\left(\mathrm{mg} \mathrm{kg}^{-1}\right)$ in the liver, kidneys, spleen and muscular tissue of Surubim fish.

\begin{tabular}{ll}
\hline Organs & Average \\
\hline Liver & $0,250 \mathrm{a}$ \\
Spleen & $0,111 \mathrm{~d}$ \\
Kidneys & $0,037 \mathrm{~b}$ \\
Muscular tissue & $0,096 \mathrm{c}$ \\
\hline CV(\%) & 70,36 \\
\hline
\end{tabular}

Averages followed by distinct letters differ amongst themselves as determined by the Tukey test $(P<0.05)$.

Table 3 presents the averages and the coefficient of variation of the lead content in each organ (liver, spleen, and kidney) in different groups (times).

Table 3: Lead levels $\left(\mathrm{mg} \mathrm{kg}^{-1}\right)$ of Surubim fish (liver, kidneys, and spleen) in different groups (times).

\begin{tabular}{llll}
\hline \multirow{2}{*}{ Groups } & \multicolumn{2}{l}{ Leads $\left(\mathrm{mg} \mathrm{kg}^{-1}\right)$} \\
\cline { 2 - 4 } & Liver & Kidneys & Spleen \\
\hline I (Nov/ 2005) & $1,39 \mathrm{a}$ & $1,63 \mathrm{a}$ & $3,02 \mathrm{a}$ \\
II (Jan/ 2006) & $0,89 \mathrm{c}$ & $1,09 \mathrm{~b}$ & $0,77 \mathrm{~d}$ \\
III (Jun/ 2006) & $0,88 \mathrm{c}$ & $0,74 \mathrm{c}$ & $0,94 \mathrm{c}$ \\
IV (Oct/ 2006) & $1,09 \mathrm{~b}$ & $0,68 \mathrm{~d}$ & $1,48 \mathrm{~b}$ \\
\hline CV (\%) & 31,00 & 43,86 & 61,86 \\
\hline
\end{tabular}

Averages followed by distinct letters differ amongst themselves as determined by the Tukey test $(P<0.05)$. 
Table 4 presents comparisons between the total average of lead in each organ (liver, spleen, kidney, and muscular tissue) and the coefficient of variation, for a possible analysis of the differences found in each organ. When compared with other tissues, the spleen was found to have the highest lead content. This high level may be related to the fact that the spleen is an organ of erythrocytes phagocytosis, thus removing erythrocytes linked to lead.

Table 4: Comparison of lead values $\left(\mathrm{mg} \mathrm{kg}^{-1}\right)$ in the liver, kidneys, spleen and muscular tissue of Surubim fish.

\begin{tabular}{ll}
\hline Organs & Average \\
\hline Liver & $1,102 \mathrm{~b}$ \\
Spleen & $1,740 \mathrm{c}$ \\
Kidneys & $0,995 \mathrm{a}$ \\
Muscular tissue & $0,578 \mathrm{~d}$ \\
\hline CV(\%) & 52,09
\end{tabular}

Averages followed by distinct letters differ amongst themselves as determined by the Tukey test $(P<0.05)$.

Table 5 presents the averages and the coefficient of variation of the cadmium content in each organ (liver, spleen, and kidney) in different groups (times). As found by De Smet et al. (2001), the common carp (Cyprinus carpio), during cadmium exposure, accumulated more cadmium in the kidney than in the liver. Only group I (Nov/2005) showed similar results to De Smet et al. (2008). However, groups III and IV were different, since in June and October 2006, the liver accumulated more cadmium than the kidney.

Table 5: Cadmium levels ( $\mathrm{mg} \mathrm{kg}^{-1}$ ) of Surubim fish (liver, kidneys, and spleen) in different groups (times).

\begin{tabular}{llll}
\hline \multirow{2}{*}{ Groups } & \multicolumn{2}{l}{ Cadmium $(\mathrm{mg} / \mathrm{kg})$} \\
\cline { 2 - 4 } & Liver & Kidneys & Spleen \\
\hline I (Nov/ 2005)* & ----- & ---- & ---- \\
II (Jan/ 2006) & $0,46 \mathrm{~b}$ & $0,70 \mathrm{a}$ & $0,47 \mathrm{a}$ \\
III (Jun/ 2006) & $0,34 \mathrm{c}$ & $0,26 \mathrm{~b}$ & $0,15 \mathrm{~b}$ \\
IV (Oct/ 2006) & $1,21 \mathrm{a}$ & $0,78 \mathrm{a}$ & $0,36 \mathrm{a}$ \\
\hline CV (\%) & 108,70 & 104,04 & 95,50 \\
\hline
\end{tabular}

*Not analysis occurred of cadmium in the group I

Averages followed by distinct letters differ amongst themselves as determined by the Tukey test $(\mathrm{P}<0.05)$

Table 6 presents the comparisons between the total average of cadmium in each organ (liver, spleen, kidney, and muscular tissue) and the coefficient of variation, for a possible analysis of the differences found in each organ. The liver was found to present the highest cadmium content when compared with the kidney and the spleen. Once again, this fact should be emphasized, since in addition to being carcinogenic (Waalkes, 2003), cadmium can cause alterations in DNA (Hartwig, 1998), and it is toxic (Fels, 1999) and teratogenic for both humans and animals.
Table 6: Comparison of cadmium levels $\left(\mathrm{mg} \mathrm{kg}^{-1}\right)$ in the liver, kidneys, spleen, and muscular tissue.

\begin{tabular}{ll}
\hline Organs & Average \\
\hline Liver & $0,805 \mathrm{a}$ \\
Spleen & $0,313 \mathrm{c}$ \\
Kidneys & $0,582 \mathrm{~b}$ \\
Muscular tissue & $0,112 \mathrm{~d}$ \\
\hline $\mathrm{CV}(\%)$ & 14,94
\end{tabular}

Averages followed by distinct letters differ amongst themselves as determined by the Tukey test $(P<0.05)$

Table 7 presents the averages and the coefficient of variation of the arsenic content ( $\mathrm{mg} \mathrm{kg}^{-1}$ ) in each organ (liver, spleen, and kidney) in different groups (times). When comparing the arsenic concentration at the different times of capture, a difference was observed in each organ in group IV (October 2006), especially in the liver.

Table 7: Arsenic levels ( $\mathrm{mg} \mathrm{kg}^{-1}$ ) of Surubim fish (liver, kidneys, and spleen) in different groups (times).

\begin{tabular}{llll}
\hline \multirow{2}{*}{ Groups } & \multicolumn{2}{l}{ Arsenic $\left(\mathrm{mg} \mathrm{kg}^{-1}\right)$} \\
\cline { 2 - 4 } & Liver & Kidneys & Spleen \\
\hline I (Nov/ 2005) & $0,015 \mathrm{c}$ & $0,02 \mathrm{~b}$ & $0,015 \mathrm{~b}$ \\
II (Jan/ 2006) & $0,020 \mathrm{~b}$ & $0,03 \mathrm{~b}$ & $0,015 \mathrm{~b}$ \\
III (Jun/ 2006) & $0,021 \mathrm{~b}$ & $0,03 \mathrm{~b}$ & $0,015 \mathrm{~b}$ \\
IV (Oct/ 2006) & $0,030 \mathrm{a}$ & $0,06 \mathrm{a}$ & $0,041 \mathrm{a}$ \\
\hline CV (\%) & 45,60 & 35,60 & 50,95 \\
\hline
\end{tabular}

Averages followed by distinct letters differ amongst themselves as determined by the Tukey test $(P<0.05)$

Table 8 presents comparisons between the total average of arsenic in each organ (liver, spleen, kidney, and muscular tissue) and the coefficient of variation. When comparing the arsenic concentration in different tissues, it was observed a difference in each organ, especially in the muscular tissue, which, though it had a low arsenic level, still presented the highest concentration among the organs. Tchounwou et al. (2003) reported that arsenic possesses carcinogenic activity, thus establishing an epidemiological association between skin, liver, and lung cancers and prolonged consumption of supply waters and contaminated wines or contact in the workplace as well as in industries that produce metallic alloys. This association shows the existence of a severe problem which these fish are consumed daily by the local population, and, in large quantities, arsenic can cause everything from skin lesions to respiratory problems, cardiovascular illnesses, neurological disturbances, and even various kinds of cancer. In fish, Yamaguchi et al. (2007) suggested that arsenic might inhibit spermatogenesis and cause necrosis of spermatogonia in male catfish (Pangasianodon hypophthalmus). 
Table 8: Comparison of arsenic levels $\left(\mathrm{mg} \mathrm{kg}^{-1}\right)$ in the liver, kidneys, spleen, and muscular tissue.

\begin{tabular}{ll}
\hline Organs & Average \\
\hline Liver & $0,023 \mathrm{c}$ \\
Spleen & $0,025 \mathrm{c}$ \\
Kidneys & $0,042 \mathrm{~b}$ \\
Muscular tissue & $0,096 \mathrm{a}$ \\
\hline CV(\%) & 37,71
\end{tabular}

Averages followed by distinct letters differ amongst themselves as determined by the Tukey test $(\mathrm{P}<0.05)$

Table 9 presents the average and the coefficient of variation of the zinc content $\left(\mathrm{mg} \mathrm{kg}^{-1}\right)$ in each organ (liver, spleen, and kidney) in different groups (times).

Table 9: Zinc levels $\left(\mathrm{mg} \mathrm{kg}^{-1}\right)$ of Surubim fish (liver, kidneys, and spleen) in different groups (times).

\begin{tabular}{llll}
\hline \multirow{2}{*}{ Groups } & \multicolumn{2}{l}{ Zinc $\left(\mathrm{mg} \mathrm{kg}^{-1}\right)$} & \\
\cline { 2 - 4 } & Liver & Kidneys & Spleen \\
\hline I (Nov/ 2005) & $76,77 \mathrm{c}$ & $31,11 \mathrm{~b}$ & $32,46 \mathrm{~b}$ \\
II (Jan/ 2006) & $57,81 \mathrm{~d}$ & $29,28 \mathrm{c}$ & $26,81 \mathrm{~d}$ \\
III (Jun/ 2006) & $97,33 \mathrm{a}$ & $40,72 \mathrm{a}$ & $46,58 \mathrm{a}$ \\
IV (Oct/ 2006) & $94,93 \mathrm{~b}$ & $24,68 \mathrm{~d}$ & $27,77 \mathrm{c}$ \\
\hline CV (\%) & 28,50 & 31,10 & 42,50 \\
\hline
\end{tabular}

Averages followed by distinct letters differ amongst themselves as determined by the Tukey test $(P<0.05)$

Table 10 presents the comparisons between the total average of zinc in each organ (liver, spleen, kidney, and muscular tissue) and the coefficient of variation. Regarding zinc, the liver was

\section{Conclusions}

The present study demonstrated that the mercury concentration was above the legal limit set forth under Brazilian law $(1.0 \mathrm{mg} /$ $\mathrm{kg}$ ) for fish predators in two liver samples and one kidney sample; the lead concentration was above the legal limit set forth under Brazilian law $(2.0 \mathrm{mg} / \mathrm{kg})$ in two liver samples, five kidney samples and 10 spleen samples; the cadmium concentration was above the legal limit set forth under Brazilian law $(1.0 \mathrm{mg} / \mathrm{kg})$ in six liver samples, seven kidney samples, and two spleen samples; the arsenic concentration was below also the organ that obtained the highest average among the other tissues. Zinc is an essential trace element, ubiquitous in soils, and fundamental to the healthy functioning of biological systems. It is also a potential toxicant when presented at elevates concentrations and it interferes in the metabolism of other minerals in the human body, especially iron and copper. The consumption of $2 \mathrm{~g}$ or more of zinc induces symptoms of poisoning including nausea, vomiting and fever (Henriques et al., 2003).

Table 10: Comparison of average levels of zinc $(\mathrm{mg} / \mathrm{kg})$ in the liver, kidneys, spleen, and muscular tissue.

\begin{tabular}{ll}
\hline Organs & Average \\
\hline Liver & $87,685 \mathrm{a}$ \\
Spleen & $33,631 \mathrm{~b}$ \\
Kidneys & $31,267 \mathrm{c}$ \\
Muscular tissue & $10,532 \mathrm{~d}$ \\
\hline CV(\%) & 24,74
\end{tabular}

Averages followed by distinct letters differ amongst themselves as determined by the Tukey test $(P<0.05)$

A quantity of zinc above the legal limit alters the fish's ability to swim against the tide and causes retarded growth, histopathologic alterations, changes in the cardiac and respiratory systems, inhibition in spawning, and even greater damage to the population, resulting in a threat to the survival of surubim (Sorensen, 1991). Therefore, this high zinc content in the samples may present a serious problem in the consumption of this fish, mostly, because the riverside populations often eat the internal organs, especially the liver which presented the highest rate of toxicity among the viscera analyzed.

These results highlight the importance of water contamination in river and exposure timing, in addition to trophic position, on Surubim fish metals bioaccumulation and risk.

the legal limit set forth under Brazilian law $(1.0 \mathrm{mg} / \mathrm{kg})$ in all liver, spleen, kidney, and muscular tissue samples; and the zinc concentration was above the legal limit set forth under Brazilian law $(1.0 \mathrm{mg} / \mathrm{kg})$ in 56 liver samples, eight kidney samples, and nine spleen samples.

A positive correlation of $72 \%$ was found between the mercury and cadmium concentrations in the liver, which were directly proportional to each other. The positive correlation between the lead and cadmium concentrations in the spleen was $82 \%$.

\section{Acknowledgement}

This work was supported by Conselho Nacional de Pesquisa e Desenvolvimento Tecnológico (CNPq).

\section{References}

AMERICAN PUBLIC HEALTH ASSOCIATION (APHA). Standard methods for examination of water and wastewater. 16. ed. New York; 1219 p., 1992.
BERVOETS, L.; VOETS, J.; COVACI, A.; CHU, S.; QADAH, D.; SMOLDERS, R., SCHEPENS, P., BLUST, R. Use of transplanted zebra mussels (Dreissena polymorpha) to assess the bioavailability of microcontaminants in Flemish surface waters. Environ. Sci. Technol. v. 39, p. 1492-1505, 2005. 
DE TEMMERMAN, L.; WAEGENEERS, N.; CLAEYS, N.; ROEKENS, E. Comparison of concentrations of mercury in ambient air to its accumulation by leafy vegetables: An important step in terrestrial food chain analysis. Environ. Pollut., v.157, p. 1337-1341, 2009.

DE SMET, H.; DE WACHTER, B.; LOBINSKI, R.; BLUST, R. Dynamics of $(\mathrm{Cd}, \mathrm{Zn})$-metallothioneins in gills, liver and kidney of common carp Cyprinus carpio during cadmium exposure. Aquat. Toxicol., v. 52, p. 269-281, 2001.

EAGLES-SMITH, C.A.; ACKERMAN, J.T.; DE LA CRUZ, S.E.W.; TAKEKAWA, J.Y. Mercury bioaccumulation and risk to three waterbird foraging guilds is influenced by foraging ecology and breeding stage. Environ. Pollut., v. 157, p. 1993-2002, 2009.

FELS, L.M. Risk assessment of nephrotoxicity of cadmium. Ren Fail; v. 21, p. 275-281, 1999.

FELTEN, V.; CHARMANTIER, G.; MONS, R.; GEFFARD, A.; ROUSSELLE, P.; COQUERY, M.; GARRIC, J.; GEFFARD, O. Physiological and behavioural responses of Gammarus pulex (Crustacea: Amphipoda) exposed to cadmium. Aquat.Toxicol., v. 86, p. 413-425, 2008.

HARTWIG, A. Carcinogenicity of metal compounds: possible role of DNA repair inhibition. Toxicol Lett., v. 102, p. 235-39, 1998.

HENRIQUES, G.S.; HIRATA, M.H.; COZZOLINO, S.M.F. Recent aspects of zinc absorption and bioavailability and correlations with physiology of the testicular Angiotensin-Converting Enzyme. Rev. Nutr., v.16, p. 333-345, 2003.

LEVESQUE, H.M., DORVAL, J., HONTELA, A., VAN DER KRAAK, G.J., CAMPBELL, P.G.C. Hormonal, morphological, and physiological responses of yellow perch (Perca flavescens) to chronic environmental metal exposures. J. Toxicol. Environ. Health Part $A$, v. 66, p. 657-676, 2003.

MAGER, E.M.; WINTZ, H.; VULPE, C.D.; BRIX, K.; GROSELL, M. Toxicogenomics of water chemistry influence on chronic lead exposure to the fathead minnow (Pimephales promelas). Aquact. Toxicol., v. 87, p. 200-209, 2008.

NOUREDDINE, D.; MILOUD, S.; ABDELKADER, A. Effect of lead exposure on dopaminergic transmission in the rat brain. Toxicol., v. 207, p. 363-368, 2005.
PACE, B.M., LAWRENCE, D.A., BEHR, P.J.P., DIAS, J.A. Neonatal lead exposure changes quality of sperm and number of macrophages in testes of BALB0c mice. Toxicol., v. 210, p. 247-256, 2005.

PATEL, M.; ROGERS, J.T.; PANE, E.F.; WOOD, C.M. Renal responses to acute lead waterborne exposure in the freshwater rainbow trout (Oncorhynchus mykiss). Aquat. Toxicol., v. 80, p. 362371, 2006.

SCHMITT, C.J., CALDWELL, C.A., OLSEN, B., SERDAR, D., COFFEY, M. Inhibition of erythrocyte delta-aminolevulinic acid dehydratase (ALAD) activity in fish from waters affected by lead smelters. Environ. Monit. Assess. v. 77, p. 99-119, 2002.

SOTO, A.M., CALABRO, J.M., PRECHYL, A.V.,YAU, A.Y., ORLANDO, E.F., DEXENBERGER, A., KOLOK, A.S., GUILETTE JR., L.J., LE BIZEC, B., LANGE, I.G., SONNENSCHEIN, C. Androgenic and estrogenic activity in water bodies receiving cattle feedlot effluent in Eastern Nebraska. USA. Environ. Health Perspect. v.112, p. 346-352, 2004.

SORENSEN, E.M. 1991. Metal Poisoning in Fish. Boca Raton, Fl, USA. CRC Press, Inc., 374 p.

TCHOUNWOU, P.B.; PATLOLLA, A.K.; CENTENO, J.A. Carcinogenic and systemic health effects associated with arsenic exposure - A Critical Review. Toxicol. Pathol., v. 31, p. 575-588, 2003.

USEPA, 2001. Update of Ambient Water Quality Criteria for Cadmium. United States Environmental Protection Agency. EPA822-R-01-001.

VIANA, F.; HUERTAS, R; DANULAT, E. Heavy Metal Levels in Fish from Coastal Waters of Uruguay. Arch. Environ. Contam. Toxicol., v. 48, p. 530-537, 2005.

WAALKES M. P. Cadmium carcinogenesis in review. J. Inorg. Biochem., v. 533, p.107-120, 2003.

YAMAGUCHI, S.; MIURA, C.; ITO, A.; AGUSA, T.; IWATA, H.; TANABE, S.; TUYEN, B.C.; MIURA, T. Effects of lead, molybdenum, rubidium, arsenic and organochlorines on spermatogenesis in fish: Monitoring at Mekong Delta area and in vitro experiment. Aquat. Toxicol., v. 83, p. 43-51, 2007. 